\title{
Comparative pharmacokinetic study of theaflavin in healthy and experimentally induced liver damage rabbits
}

\author{
S.R. Sarhan \\ Department of Pharmacology and Physiology, College of Veterinary Medicine, University of Wasit, Wasit, Iraq \\ Email: srashid@uowasit.edu.iq
}

(Received June 10, 2018; Accepted November 27, 2018)

\begin{abstract}
This current work aimed to study the pharmacokinetics of theaflavin in healthy and hepatotoxic rabbits for comparison. Aspartate aminotransferase (AST), alkaline phosphatase (ALP) and alanine aminotransferase (ALT) were significantly raised $(\mathrm{P}<0.05)$ after administration of $0.2 \mathrm{mg} / \mathrm{kg}$ body weight (BW) Carbone tetrachloride (CCL4) subcutaneously. Pharmacokinetic parameters calculated following administration of theaflavin intravenously and orally at $30 \mathrm{mg} / \mathrm{kg}$ and $500 \mathrm{mg} / \mathrm{kg}$ respectively to both healthy animals and those with damaged liver. Theaflavin concentration in blood measured by HLPC at various time intervals. Pharmacokinetic results showed that theaflavin concentration when given orally reached its maximum concentration after 5 hours in healthy rabbits. While in hepatotoxic group, theaflavin concentration achieved the highest level in blood after three hours. Theaflavin bioavailability in hepatotoxic animals was significantly high and almost double its bioavailability in healthy animals. Results revealed that the area under curve (AUC) value in rabbits with damaged liver was significantly greater than in healthy group $(\mathrm{P}<0.05) . \mathrm{t} 1 / 2$ of theaflavin after intravenous administration was $6.3 \pm 0.82$ hour in damaged liver group which is significantly higher than that in healthy group $(\mathrm{P}<0.05)$. Theaflavin mean concentration in hepatotoxic group required more than 3 hours to decline to $352 \pm 19.4 \mathrm{ng} / \mathrm{ml}$ when compared to its concentration in healthy group which is required only 45 minutes to decrease to $310 \pm 9.5 \mathrm{ng} / \mathrm{ml}$. In conclusion liver has critical impact on the pharmacokinetics of theaflavin especially bioavailability and biotransformation and this research recorded reasonably large differences between healthy and liver damaged groups regarding theaflavin pharmacokinetic parameters which may result in negative influences on its biological efficacy when used in the treatment of various diseases.
\end{abstract}

Keyword: Pharmacokinetics, Theaflavin, Carbon tetrachloride, Hepatotoxicity, Rabbits.

Available online at http://www.vetmedmosul.com

\section{دراسة مقارنة الحركة الدوائية للثيفلافين في الأرانب السليمة والمصابة بتلف الكبد المستحدث تجريبياً سرحان راشد سرحان$$
\text { فرع الفسلجة والأدوية، كلية الطب البيطري، جامعة واسط، واسط، العراق }
$$

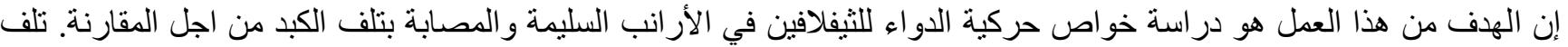

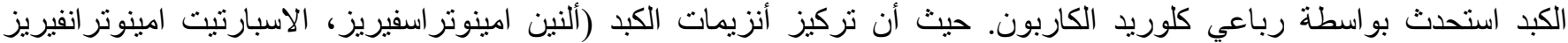

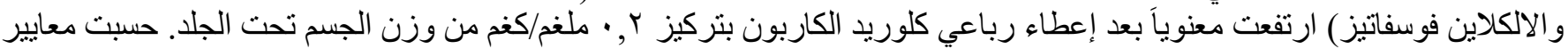

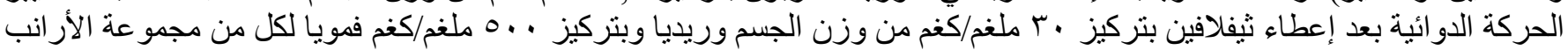

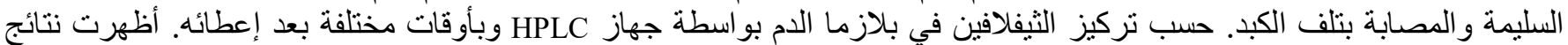

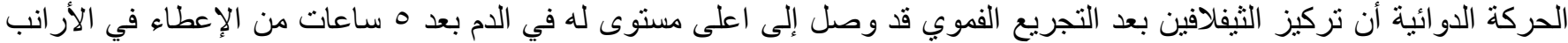

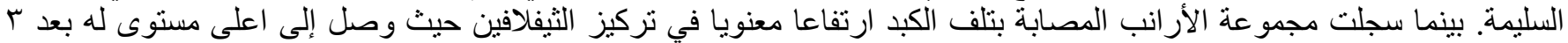




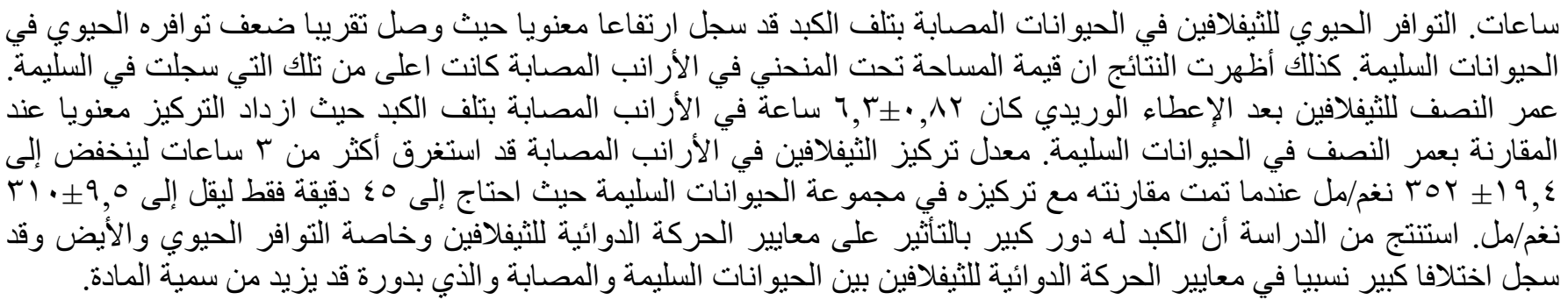

\section{Introduction}

Camellia sinensis is a plant family that the traditional tea produces from their leaves. Tea is the most beverage consumed in the world after water (1). Tea was initially utilized as a traditional medicine and later as a daily basis beverage and there are four unique kinds of tea are white, black, green and oolong tea (2). Tea has a complex chemical composition with several components: proteins, polysaccharides, amino acids, organic acids, minerals, chlorophyl, lignins, volatile compounds, polyphenols (proanthocyanidins theaflavins and thearubigins) and also alkaloids such as (caffeine theophylline and theobromiine) (3). Caffeine is the most plentiful alkaloid in tea (4). Theaflavins and thearubigins are the most essential polyphenols in traditional black tea, they are formed from tea leaves fermentation by catechins polymerization and oxidation. Theaflavins and catechins represent $2-6 \%$ and 3$10 \%$, respectively while thearubigins represent greater than $20 \%$ of the aqueous extract of black tea (5-7). Recently, theaflavins have established wide attentions because of their anti-oxidant, anti-inflammatory, and anti-tumor activities $(8,9)$.

Thearubigins are a very complex polymers with high molecular weight $(10,11)$. While theaflavins are a little simpler structure in different five forms; theaflavin 5, theaflavin-3-O-gallate 6, theaeflavin-3'-Ogallate 7, and theaeflavin-3,3'-O-digalate 8 . These different types of theaflavin are the essential components of black tea with a potential bioactive in which associated to beneficial effects on health $(12,9)$. There are many in-vitro and in-vivo studies reported the activity of theaflavins against proinflammatory cytokines like inhibition of interleukins-6 (IL-6), interleukins 1 beta (IL-1 $\beta$ ) and tumor necrosis factor alpha (TNF- $\alpha$ ). In addition, it prevents DNA damage in lymphocytes $(13,14)$. Furthermore, it suppresses the free radicals formation by preserving the activities of antioxidants (15). It has been shown that theaflavin has antihypertensive activity in people who consuming black tea for long time regularly (16), also theaflavin decreases the plasma creative protein and reduce the activation of platelet in healthy people (17). Moreover, some prospective studies demonstrated a relation between black tea intake and the prevalence of different cancers (18-20).
Sarkar and Bhaduri (21) approved that constituents of black tea especially theaflavins are more effective than green tea in abolishing $\mathrm{NO}$ and $\mathrm{O}_{2}$ production in activated macrophages. The main difficulty in examining the relationship of tea consumption with biological activity is the absence of adequate quantitative data. Even in animal studies, understanding the inhibitory mechanism of tea action on different disease is vulnerable by a little and limited information about the pharmacokinetics profile such as bioavailability, biotransformation and clearance of tea constituents (22).

In my opinion the advantages of green tea over black tea in relation to health benefit is basically because of the data of black tea therapeutic effects of black tea on health are insufficient. Therefor information on the absorption, distribution and bioavailability of theaflavin is critical for understanding the biological benefits of black tea. Subsequently, there are few researches have been studied the pharmacokinetics of the black tea (22-25). The objective of this research is to estimate the pharmacokinetic parameters of theaflavin in healthy and hepatotoxic rabbits to understand the role of liver in biotransformation and bioavailability of theaflavin.

\section{Materials and methods}

\section{Preparation of Theaflavin stock solution}

Theaflavin obtained from (Aktin Chemicals, Inc. India). The solution was prepared by dissolving of $1 \mu \mathrm{g}$ of theaflavin in $1 \mathrm{ml}$ of double sterile distilled water.

\section{Experimental Animals}

Ninety-six healthy male rabbits (local breed rabbits), their ages and weights ranged between 13-15 weeks and 1.5 - $2 \mathrm{~kg}$, respectively were used in this work. Rabbits were kept in standard cages, located in a special animal house. Rodent diet pellets and water were provided for two weeks for adaption before experiments, then animals were kept in fasting state prior to starting any experiment started. Housing conditions were maintained at $20-25{ }^{\circ} \mathrm{C}$ in controlled room condition, the air of the room was changed continuously by using ventilation vacuum. Cages were cleaned daily. All experiments were done according to 
research protocols established by the animal care committee of the Veterinary Medicine College, Wasit University.

\section{Induction of hepatic injury}

The chemical agent used for inducing hepatic injury was " $\mathrm{CCl}_{4}$ " (Sigma Chemicals, USA). It was given subcutaneously to 48 rabbits every alternate day for 3 weeks with a dose of $0.2 \mathrm{ml} / \mathrm{kg}(26)$.

\section{Liver enzyme estimation}

Biomeruix kit, (France) was used to measure "Alanine aminotransferase (ALT) Aspartate aminotransferase (AST), and Alkaline phosphatase (ALP)" according to standard laboratory methods.

Pharmacokinetics study of theaflavin in healthy animals

A 24 rabbits were given $500 \mathrm{mg} / \mathrm{kg}$ of theaflavin as single oral dose. Blood samples were collected at various times; $10 \mathrm{~min}, 30 \mathrm{~min}, 1 \mathrm{hr}, 3 \mathrm{hr}, 5 \mathrm{hr}, 8 \mathrm{hr}, 12 \mathrm{hr}$ and $24 \mathrm{hrs}$. Likewise 24 rabbits given $30 \mathrm{mg} / \mathrm{kg}$ of theaflavin as a single intravenous dose. Blood samples were collected at various times; 5 $\mathrm{min}, 15 \mathrm{~min}, 45 \mathrm{~min}$, $3 \mathrm{hrs}$, 5hrs, $8 \mathrm{hrs}$, $12 \mathrm{hrs}$ and 24hrs (27). Three animals used for each withdrawal time.

\section{Study the pharmacokinetics of theaflavin in damaged liver animals}

A 24 rabbits administrated single oral $(500 \mathrm{mg} / \mathrm{kg})$ dose of theaflavin. Similarly, 24 rabbits administrated a single intravenous $(30 \mathrm{mg} / \mathrm{kg})$ dose of theaflavin similar to procedure in healthy animals. Three animals used for each withdrawal time. Animals were anesthetized by intramuscular injection of Xylazine 2\% (VMD, Belgium) 4 $\mathrm{mg} / \mathrm{kg}$ and Ketamine 10\% (Fabrique par: KEPRO, Netherland) $50 \mathrm{mg} / \mathrm{kg}$ (28). Four $\mathrm{ml}$ of blood sample was withdrawn from the heart of each rabbits (each time interval for all animals), then blood samples were centrifuged at $2000 \mathrm{~g}$ for ten minutes. One $\mathrm{ml}$ of plasma mixed thoroughly with $20 \mathrm{ml}$ of ascorbic-EDTA solution [0.1\% EDTA (pH 3.6) and $0.4 \mathrm{M} \mathrm{NaH}_{2} \mathrm{PO}_{4}$ buffer containing $20 \%$ ascorbic acid], then stored at $-80^{\circ} \mathrm{C}$ until analyzed (29).

\section{Pharmacokinetic parameters}

Elimination rate constant $\left(\mathrm{Ke} \mathrm{hr}^{-1}\right)$ Absorption rate constant $\left(\mathrm{Ka} \mathrm{hr}^{-1}\right)$, concentrations of theaflavin at time zero $\mathrm{ng} / \mathrm{ml}$, volume of distribution ( $\mathrm{vd})(\mathrm{L} / \mathrm{Kg}), \mathrm{t} 1 / 2 \mathrm{a}(\mathrm{hr}), \mathrm{t} 1 / 2 \mathrm{e}$ (hr), area under concentration curve (AUC) ng/ml.hr, Tmax, Cmax clearance (CL) L/Kg/hr and Bioavailability F $\%$ were calculated to estimate the pharmacokinetics parameters.

\section{Quantitative determination of theaflavin}

Determination of theaflavin in plasma was conducted by using HPLC, procedure described by Lee (29) with slight alteration. "The HPLC system consisted of an ESA two- pump solvent delivery system, and a supelcosil C18 reversed-phase column $(150 \times 4.6 \mathrm{~mm}$; particle size, $5 \mu \mathrm{m})$ and an ESA model 540 refrigerated autosampler. Buffer A consisted of $30 \mathrm{~mm} \mathrm{NaH} \mathrm{PO}_{4}$, acetonitrile, and tetrahydrofuran in a ratio of 98.13:1.75:0.12 (pH 3.35). Buffer B consisted of $15 \mathrm{~mm} \mathrm{NaH} \mathrm{PO}_{4}$, acetonitrile, and tetrahydrofuran in a ratio of 41.5:58.5:12.5 (pH 3.45)". The flow rate was maintained at $1 \mathrm{ml} / \mathrm{min}$. fifty microliter of the sample were injected onto the HPLC (29).

\section{Standard Curves and Calculation}

Standard curve in figure 1 was accomplished by spike plasma samples with known concentrations of stander theaflavin 32, 64, 128, 256, 512, 1024, and $2048 \mathrm{ng} / \mathrm{ml}$. The peak heights were plotted against the sample concentration. Analytes concentrations were attained by comparing the peak heights of the sample to standard.

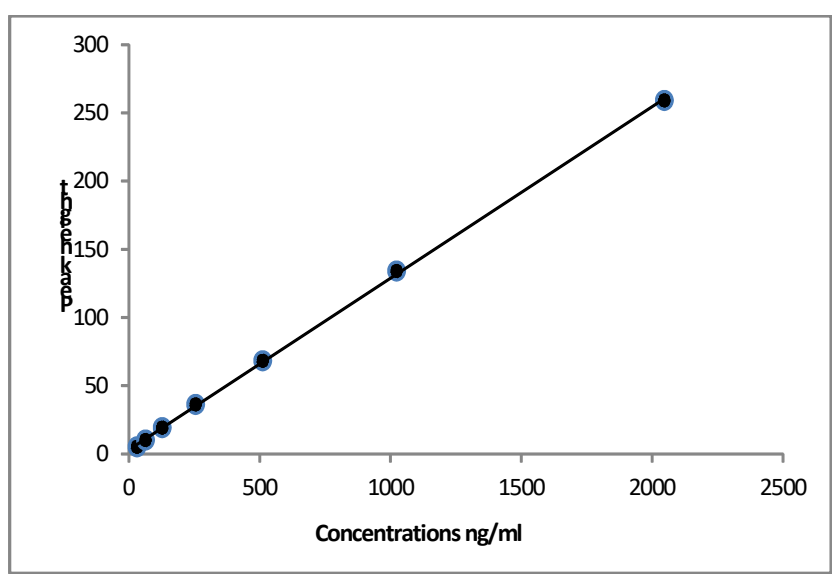

Figure 1: Standard curve of theaflavin in plasma.

\section{Statistical analysis}

The data was collected and reported as mean \pm SE. SPSS software (30) used to find out the significant result. Continuous and numerical values were analyzed by student t-test. P-value $<0.05$ were considered as significant difference between groups or periods.

\section{Results}

\section{Liver enzyme analysis}

The results in table 1 revealed severe liver damage in rabbits injected with $0.2 \mathrm{ml} / \mathrm{kg}$ CCL4 in alternate days for 3 weeks when compared to rabbits before injection. This was evidenced by a mark increased of serum enzymes level (ALT, AST and ALP) in rabbits treated with $\mathrm{CCl}_{4}$.

\section{Pharmacokinetics analysis}

Theaflavin was analyzed in blood samples of all animals before experiments begun to assure that animals clean from 
theaflavin by using HPLC (method mention previously). Theaflavin was not found in plasma samples from all experimental animals.

Results of the theaflavin concentrations in plasma versus time after intravenous administration in both healthy and damaged liver rabbits displayed bi-exponential elimination that obey first order kinetics, two compartment model (according to Plasma concentration-time curve).

Theaflavin mean concentration in blood plasma of healthy rabbits after IV administration of $30 \mathrm{mg} / \mathrm{kg}$ was $640 \pm 22.4 \mathrm{ng} / \mathrm{ml}$ after 5 minutes then, after $24 \mathrm{hr}$, the concentration decreased to $3 \pm 0.3 \mathrm{ng} / \mathrm{ml}$. While its concentration in hepatotoxic rabbits after IV administration was $730 \pm 20.3 \mathrm{ng} / \mathrm{ml}$ after 5 minutes, whereas after $24 \mathrm{hr}$ the concentration was decrease to $166 \pm 12.7 \mathrm{ng} / \mathrm{ml}$ as shown in table 2, figures 2 and 3, respectively.

The highest level that theaflavin concentration reached after 5 hours of oral dosing of $500 \mathrm{mg} / \mathrm{kg}$ was $143 \pm 6.2$ $\mathrm{ng} / \mathrm{ml}$ in healthy animals. Then, theaflavin concentration reduced to $8 \pm 1.2 \mathrm{ng} / \mathrm{ml}$ after $24 \mathrm{hr}$, whereas in hepatotoxic group its concentration required only $3 \mathrm{hrs}$ following administration to achieved peak level $172 \pm 3.7 \mathrm{ng} / \mathrm{ml}$. Then the concentration declined after $24 \mathrm{hrs}$ to $102 \pm 3.3 \mathrm{ng} / \mathrm{ml}$, as shown in table 3 , figures 4 and 5 .

Table 1: Serum liver enzymes in experimentally liver damaged group

\begin{tabular}{lcc}
\hline Liver & \multicolumn{2}{c}{ Group $(\mathrm{n}=30)$} \\
\cline { 2 - 3 } enzymes & $\begin{array}{c}\text { Before treated with } \\
\mathrm{CCl}_{4}\end{array}$ & $\begin{array}{c}\text { After treated with } \\
\mathrm{CCl}_{4}\end{array}$ \\
\hline ALT (U/I) & $44.3 \pm 3.11 \mathrm{~A}$ & $134.7 \pm 7.12 \mathrm{~B}$ \\
AST (U/I) & $36.7 \pm 5.32 \mathrm{~A}$ & $210.8 \pm 10.83 \mathrm{~B}$ \\
ALP (U/L) & $112.3 \pm 6.55 \mathrm{~A}$ & $243.6 \pm 8.33 \mathrm{~B}$ \\
\hline
\end{tabular}

Values are expressed as mean \pm standard error, Different capital letters mean significant $(\mathrm{P} \leq 0.05)$ results between periods. AST: Aspartate aminotransferase, ALT: Alanine aminotransferase, ALP: Alkaline phosphatase.

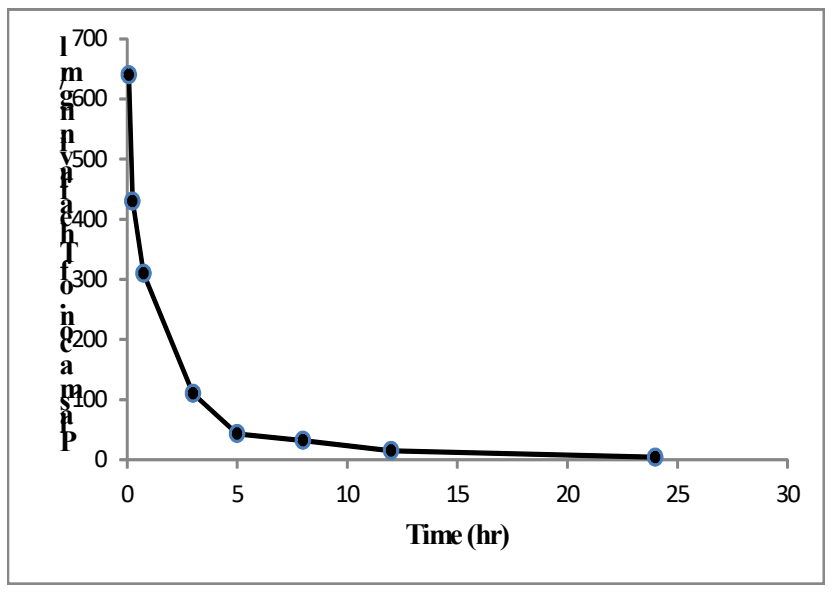

Figure 2: Plasma concentrations of Theaflavin versus time profile after a single IV ( $30 \mathrm{mg} / \mathrm{kg})$ administration in healthy animals.

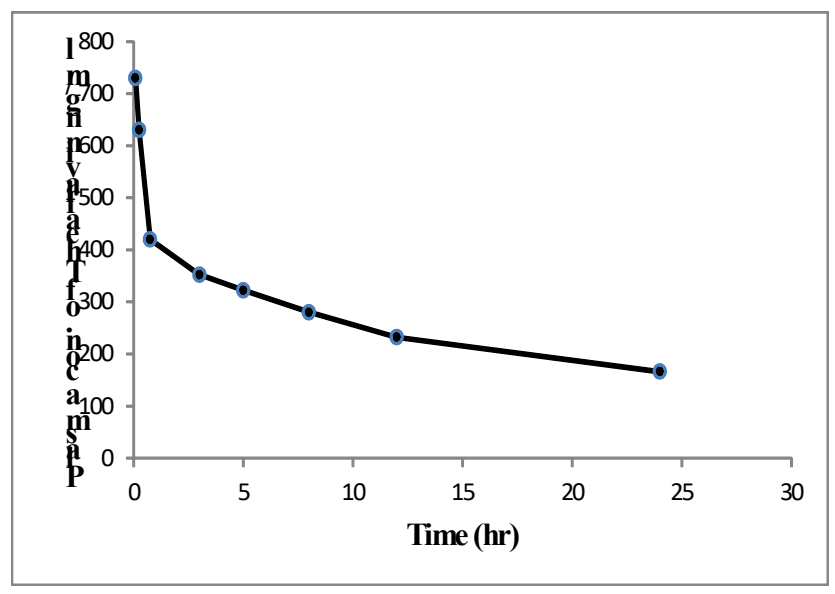

Figure 3: Plasma concentrations of Theaflavin versus time profile after a single IV $(30 \mathrm{mg} / \mathrm{kg})$ administration in liver damaged animals.

Table 2: Plasma concentrations of theaflavin at different times interval after single IV (30 $\mathrm{mg} / \mathrm{kg})$ administration in healthy and hepatotoxic animals

\begin{tabular}{|c|c|c|c|c|c|c|c|c|}
\hline \multicolumn{9}{|c|}{ Single IV $(30 \mathrm{mg} / \mathrm{kg})$ in healthy group $(\mathrm{n}=24)$} \\
\hline Times & $5 \mathrm{~min}$ & $15 \mathrm{~min}$ & $45 \mathrm{~min}$ & $3 \mathrm{hr}$ & $5 \mathrm{hr}$ & $8 \mathrm{hr}$ & $12 \mathrm{hr}$ & $24 \mathrm{hr}$ \\
\hline Concentrations (ng/ml) & $640 \pm 22.4$ & $430 \pm 21.9$ & $310 \pm 9.5$ & $110 \pm 6.5$ & $41 \pm 2.3$ & $31 \pm 1.5$ & $15 \pm 0.8$ & $3 \pm 0.3$ \\
\hline & $\mathrm{a}$ & $\frac{b}{\text { sle IV }(30 n}$ & $\frac{b}{g / k g) \text { in } h a}$ & $\frac{b}{a t a t o x i c o r}$ & $\frac{b}{n(n=24)}$ & $\mathrm{b}$ & $\mathrm{b}$ & $\mathrm{b}$ \\
\hline Times & $5 \mathrm{~min}$ & $15 \mathrm{~min}$ & $45 \mathrm{~min}$ & $3 \mathrm{hr}$ & $5 \mathrm{hr}$ & $8 \mathrm{hr}$ & $12 \mathrm{hr}$ & $24 \mathrm{hr}$ \\
\hline Concentrations (ng/ml) & $\begin{array}{c}730 \pm 20.3 \\
a\end{array}$ & $\begin{array}{c}630 \pm 26.9 \\
a\end{array}$ & $\begin{array}{c}420 \pm 23.2 \\
\mathrm{a}\end{array}$ & $\begin{array}{c}352 \pm 19.4 \\
\mathrm{a}\end{array}$ & $\begin{array}{c}322 \pm 18.1 \\
a\end{array}$ & $\begin{array}{c}280 \pm 20.2 \\
\mathrm{a}\end{array}$ & $\begin{array}{c}232 \pm 10.6 \\
a\end{array}$ & $\begin{array}{c}166 \pm 12.7 \\
\mathrm{a}\end{array}$ \\
\hline
\end{tabular}

Values are expressed as mean \pm standard error, Group no $=24$, three animals used for each withdrawal time. Different small letters mean significant $(\mathrm{p}<0.05)$ results between groups. 
Table 3: Plasma concentrations of theaflavin at different times interval after single oral $(500 \mathrm{mg} / \mathrm{kg})$ administration in healthy and hepatotoxic groups

\begin{tabular}{|c|c|c|c|c|c|c|c|c|}
\hline \multicolumn{9}{|c|}{ Single oral $(500 \mathrm{mg} / \mathrm{kg})$ in healthy group $(\mathrm{n}=24)$} \\
\hline Times & $10 \mathrm{~min}$ & 30min & $1 \mathrm{hr}$ & $3 \mathrm{hr}$ & $5 \mathrm{hr}$ & $8 \mathrm{hr}$ & $12 \mathrm{hr}$ & $24 \mathrm{hr}$ \\
\hline \multirow{2}{*}{ Concentrations $(\mathrm{ng} / \mathrm{ml})$} & $12 \pm 1.7$ & $43 \pm 2.8$ & $83 \pm 2.3$ & $110 \pm 5.3$ & $143 \pm 6.2$ & $118 \pm 3.1$ & $62 \pm 4.1$ & $8 \pm 1.2$ \\
\hline & $\mathrm{a}$ & $\mathrm{a}$ & $\mathrm{a}$ & $\mathrm{b}$ & $\mathrm{b}$ & $\mathrm{b}$ & $\mathrm{b}$ & $\mathrm{b}$ \\
\hline \multicolumn{9}{|c|}{ Single oral $(500 \mathrm{mg} / \mathrm{kg})$ in hepatotoxic group $(\mathrm{n}=24)$} \\
\hline Times & $10 \mathrm{~min}$ & $30 \mathrm{~min}$ & $1 \mathrm{hr}$ & $3 \mathrm{hr}$ & $5 \mathrm{hr}$ & $8 \mathrm{hr}$ & $12 \mathrm{hr}$ & $24 \mathrm{hr}$ \\
\hline \multirow{2}{*}{ Concentrations (ng/ml) } & $23 \pm 1.08$ & $45 \pm 2.3$ & $86 \pm 2.7$ & $172 \pm 3.7$ & $168 \pm 3.2$ & $150 \pm 3.1$ & $143 \pm 2.4$ & $102 \pm 3.3$ \\
\hline & $\mathrm{a}$ & $\mathrm{a}$ & $\mathrm{a}$ & a & $\mathrm{a}$ & $\mathrm{a}$ & $\mathrm{a}$ & $\mathrm{a}$ \\
\hline
\end{tabular}

Values are expressed as mean \pm standard error, Group no $=24$, three animals used for each withdrawal time. Different small letters mean significant $(\mathrm{p}<0.05)$ results between groups.

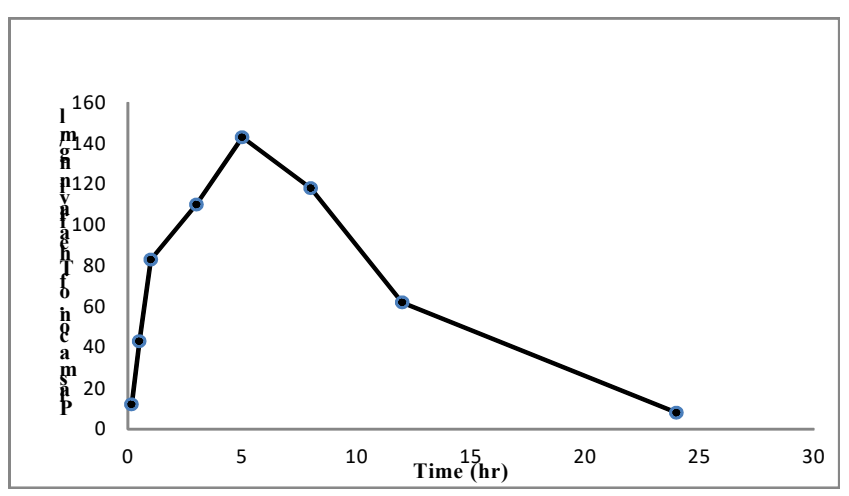

Figure 4: Plasma concentrations of Theaflavin versus time profile after a single oral ( $500 \mathrm{mg} / \mathrm{kg}$ ) administration in healthy animals.

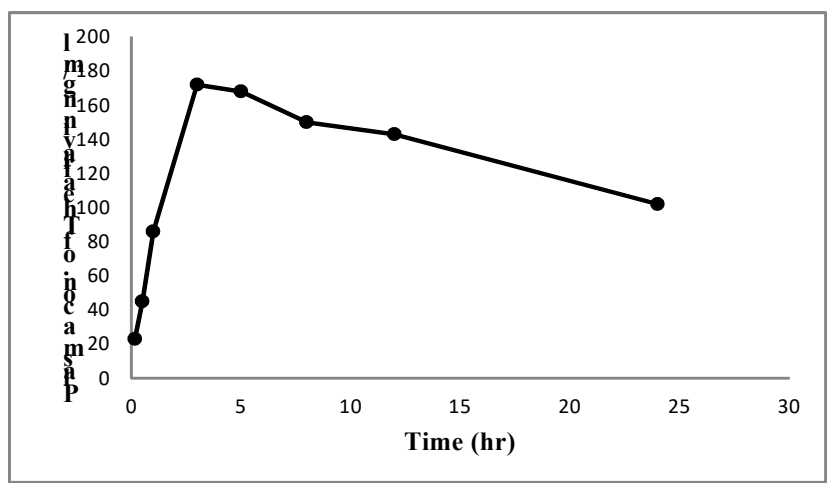

Figure 5: Plasma concentrations of Theaflavin versus time profile after a single oral ( $500 \mathrm{mg} / \mathrm{kg}$ ) administration in liver damaged liver animals.

The average pharmacokinetic parameter of theaflavin following oral dosing and IV administration in healthy and hepatotoxic animals shown in tables 4 and 5. Theaflavin concentrations following IV administration at time zero in healthy rabbits' group in $\alpha$ and $\beta$ phases were $61.94 \pm 4.65$ and $86.24 \pm 4.14 \mathrm{ng} / \mathrm{ml}$, respectively. While in hepatotoxic rabbits group the average concentration found to be $231 \pm 7.82$ and $413 \pm 10.31 \mathrm{ng} / \mathrm{ml}$, respectively. Results confirmed that the concentrations at time zero in both phases for hepatotoxic group were significantly $(\mathrm{P}<0.05)$ greater than what were recorded in healthy group. While following oral dosing there was no significant differences in mean concentrations at time zero between the two groups.

The apparent volume of distribution (Vd) of theaflavin in hepatotoxic group following IV administration was significantly $(\mathrm{P}<0.05)$ higher than that recorded in healthy group. Also, it was recorded that the $t 1 / 2$ of theaflavin in healthy group after iv administration was $4.95 \mathrm{hr}$. Whereas it was increased to $6.3 \mathrm{hr}$ in hepatotoxic group. While after oral dosing the $t \frac{1}{2}$ increased from $4.62 \mathrm{hrs}$ in healthy group to $5.8 \mathrm{hrs}$ in hepatotoxic group.

There were noticeable significant differences $(\mathrm{P}<0.05)$ in clearance of theaflavin between the healthy rabbits and those with damaged liver either after IV or oral administration. Additionally, results showed that clearance significantly decreased in hepatotoxic group.

\section{Discussion}

$\mathrm{CCL}_{4}$ is a very familiar toxicant agent which causes liver damage and it converts to trichloromethyl free radicals a highly reactive metabolites by the action of liver cytochrome P-450 enzymes (31). These free radicals may again react with oxygen to form trichloromethyl peroxyl radicals, which may attack lipids on the membrane of endoplasmic reticulum to elicit lipid peroxidation, finally resulting in cell necrosis and consequent cell death $(31,32)$. In the present study, all animals that dosed with $\mathrm{CCL}_{4}$ demonstrated significant liver damage which was reflected through a considerable rise in the serum enzymes "AST and ALT and ALP". Serum aminotransferases considered as sensitive indicator of hepatic injury. Results in agreement with Alaraj and Qiblawi whose recorded elevation of serum enzymes after treatment of rabbits with $\mathrm{CCL}_{4}(33)$. 
Table 4: Pharmacokinetic parameters for Teaflavin after IV $(30 \mathrm{mg} / \mathrm{kg})$ administration in healthy and hepatotoxic rabbits

\begin{tabular}{lcc}
\hline \multirow{2}{*}{ Pharmacokinetics parameters } & \multicolumn{2}{c}{ Mean \pm SE } \\
\cline { 2 - 3 } & Healthy group & Hepatotoxic group \\
\hline Distribution rate constant $(\alpha) \mathrm{hr}^{-1}$ & $0.73 \pm 0.12 \mathrm{~A}$ & $0.62 \pm 0.05 \mathrm{~A}$ \\
Elimination rate constant $(\beta) \mathrm{hr}^{-1}$ & $0.14 \pm 0.01 \mathrm{~A}$ & $0.03 \pm 0.01 \mathrm{~B}$ \\
Concentration $\mathrm{ng} / \mathrm{ml}$ in $\alpha$ phase at time zero (A) & $61.94 \pm 4.65 \mathrm{~B}$ & $231 \pm 7.82 \mathrm{~A}$ \\
Concentration $\mathrm{ng} / \mathrm{ml}$ in $\beta$ phase at time zero (B) & $86.24 \pm 4.14 \mathrm{~B}$ & $413 \pm 10.31 \mathrm{~A}$ \\
$\mathrm{t} 1 / 2 \alpha \mathrm{hr}$ & $0.94 \pm 0.07 \mathrm{~A}$ & $1.11 \pm 0.52 \mathrm{~A}$ \\
$\mathrm{t} 1 / 2 \beta \mathrm{hr}$ & $4.95 \pm 1.02 \mathrm{~B}$ & $6.3 \pm 0.82 \mathrm{~A}$ \\
Volume of distribution $\mathrm{Vd}(\mathrm{L} / \mathrm{kg})$ & $1.26 \pm 0.43 \mathrm{~B}$ & $2.5 \pm 0.14 \mathrm{~A}$ \\
Area under curve AUC $(\mathrm{ng} / \mathrm{ml} / \mathrm{hr})$ & $65 \pm 0.83 \mathrm{~A}$ & $75 \pm 1.58 \mathrm{~A}$ \\
Clearance CL $(\mathrm{L} / \mathrm{kg} / \mathrm{hr})$ & $0.17 \pm 0.02 \mathrm{~B}$ & $0.07 \pm 0.007 \mathrm{~A}$ \\
\hline
\end{tabular}

Values represent mean \pm SE, Group no $=24$,three animals used for each withdrawal time.

Different capital letters mean significant $(\mathrm{p}<0.05)$ results between groups.

Table 5: Pharmacokinetic parameters for Teaflavin after oral $(500 \mathrm{mg} / \mathrm{kg})$ administration in healthy and hepatotoxic rabbits

\begin{tabular}{lcc}
\hline \multirow{2}{*}{ Pharmacokinetics parameters } & \multicolumn{2}{c}{ Mean \pm SE } \\
\cline { 2 - 3 } & Healthy group & Hepatotoxic group \\
\hline Absorption rate constant $(\mathrm{Ka}) \mathrm{hr}^{-1}$ & $1.4 \pm 0.09 \mathrm{~B}$ & $2.4 \pm 0.23 \mathrm{~A}$ \\
Elimination rate constant $(\mathrm{Ke}) \mathrm{hr}^{-1}$ & $0.15 \pm 0.01 \mathrm{~A}$ & $0.04 \pm 0.01 \mathrm{~B}$ \\
Conentration $(\mathrm{ng} / \mathrm{ml})$ in absorption phase at time zero $\left(\mathrm{CP}^{\mathrm{a}}\right)$ & $210 \pm 9.87 \mathrm{~A}$ & $234 \pm 21.19 \mathrm{~A}$ \\
Concentration $(\mathrm{ng} / \mathrm{ml})$ in elimination phase at time zero $\left(\mathrm{CP}^{\mathrm{e}}\right)$ & $368 \pm 11.15 \mathrm{~A}$ & $420 \pm 11.32 \mathrm{~A}$ \\
$\mathrm{t} 1 / 2 \mathrm{a} \mathrm{hr}$ & $0.32 \pm 0.04 \mathrm{~B}$ & $1.6 \pm 0.15 \mathrm{~A}$ \\
$\mathrm{t} 1 / 2 \mathrm{e} \mathrm{hr}$ & $4.62 \pm 1.11 \mathrm{~A}$ & $5.8 \pm 0.17 \mathrm{~A}$ \\
Volume of distribution $\mathrm{Vd}(\mathrm{L} / \mathrm{kg})$ & $2.3 \pm 0.12 \mathrm{~A}$ & $1.6 \pm 0.13 \mathrm{~A}$ \\
Area under curve AUC $(\mathrm{ng} / \mathrm{ml}$ ( $\mathrm{hr})$ & $20 \pm 0.14 \mathrm{~B}$ & $45 \pm 4.46 \mathrm{~A}$ \\
Clearance CL $(\mathrm{L} / \mathrm{kg} / \mathrm{hr})$ & $0.18 \pm 0.03 \mathrm{~A}$ & $0.04 \pm 0.02 \mathrm{~B}$ \\
Bioavailability F \% & $30 \pm 2.23 \mathrm{~B}$ & $60 \pm 3.88 \mathrm{~A}$ \\
$\mathrm{C}_{\max }(\mathrm{ng} / \mathrm{ml})$ & $143 \pm 5.42 \mathrm{~B}$ & $172 \pm 8.52 \mathrm{~A}$ \\
$\mathrm{~T}_{\max }(\mathrm{hr})$ & $5 \pm 1.3 \mathrm{~A}$ & $3 \pm 0.29 \mathrm{~B}$ \\
\hline
\end{tabular}

Values represent mean \pm SE, Group no $=24$,three animals used for each withdrawal time.

Different capital letters mean significant $(\mathrm{p}<0.05)$ results between groups.

In this study theaflavin concentration following oral dosing reached the Cmax after 5hrs in healthy rabbits. While in hepatotoxic group, theaflavin concentration achieved highest concentration in blood after $3 \mathrm{hrs}$. This delay in absorption and reaching the maximum plasma concentration may be attributed to the use of pure theaflavin rather than black tea extract. This may clarify why in other study (34) the polyphenols in black tea reached the Cmax faster than what has been obtained in this study.

However, there were little information and limited studies focused on the absorption, metabolism and intestinal flora catabolism of black tea derived polyphenols. The bioavailability of theaeflavin in hepatotoxic animals was significantly high and almost double the bioavailability in healthy animals. Also, the results revealed that the AUC in damaged liver rabbits were considerably greater than those recorded in healthy group. A study reported when increase in in the pre-systemic elimination and the catabolism within the gut may contribute more significantly to decreases the oral bioavailability (35).

Sherry Chow and his colleagues reported that following oral dosing, the tea polyphenols are likely to be eliminated pre-systemically (23). Small changes in the pre-systemic elimination of green tea could have a significant impact on the systemic bioavailability of these compounds. This study verified increasing in the bioavailability and AUC in hepatotoxic rabbits and this is because of the damage occurred in liver which affects negatively the metabolic mechanism of theaflavin (23).

Major metabolites of theaeflavin 3,3'- digallate after biotransformation of theaflavins and thearubigines are theaeflavin 3-gallate, theaeflavin 3'-gallate, methylated theaflavin 3,3'-digallate, and gallic acid were found in mouse fecal sample. Neither glucuronidated nor sulfated metabolites were detectable. Gut microflora or "Cattechol- 
O-methyltransferasee (COMT)" metabolize the theaeflavin 3,3'-digallatte to form gallic acid, theaflavin and theaeflavin mono-gallate (36).

Tea polyphenols biotransformation occur mainly in Phase II metabolism by glucuronidation and glucosidation. In-vitro and in-vivo studies constantly show rapid conjugation, particularly conjugation with glucuronic acid in the liver and intestine $(37,38)$, Glucuronidation along with factors like stability and solubility are predominantly accountable for the poor bioavailability of phenolics. Glucuronidation is mediated by UDP glucuronosyltransferases (UGTs) while sulfation is mediated by sulfotransferases (SULT) and along with cytochrome P450 enzymes, which represent more than eighteen percent of the metabolic pathways $(39,40)$. Also, the colonic microflora largely responsible for the metabolism of theaflavin in both human and mice $(41,36)$.

Relative rabid clearance of theaflavin after IV administration may have occurred as a result of its significant accumulation by the kidney and slightly by the spleen and liver as demonstrated by tissue distribution (22). Same study reported after 30 minutes, $36 \%$ of theaflavin administration was recovered in the kidney, whereas $12 \%$ in the liver and $7.5 \%$ in the spleen.

Sulfotransferase and UDP-glucuronyl transferase are the essential enzymes for biotransformation of tea polyphenols in liver (41). Therefore, in this research liver toxicity caused by $\mathrm{CCl}_{4}$ may led to decrease in the activity of these two enzymes which contributed more in decreasing the theaflavin metabolism in the liver. This might be explaining the increased the $t \frac{1}{2}$ and the decreased clearance in comparison with healthy rabbits. In conclusion, results of this study established that the liver has critical impact on the pharmacokinetics properties of theaflavin especially bioavailability and biotransformation. Additionally, the difference in pharmacokinetic parameters of theaflavin between the two studied groups may influence its therapeutic efficacy when used in various diseases

\section{References}

1. Khan N, Mukhtar H. Tea polyphenols for health promotion. Life Sci. 2007;81(7):519-533. DOI: 10.1016/j.1fs.2007.06.011.

2. Monsanto MFM. Separation of polyphenols from aqueous green and black tea Eindhoven [MSc thesis] Technische: Universiteit Eindhoven; 2015, Pp: 22-27. DOI:10.6100/IR784499.

3. Harbowy ME, Balentine DA. Tea chemistry. Critica Rev in Plant Sci. 1997;16(5):415-480. DOI: 10.1080/07352689709701956.

4. Hilal Y, Engelhardt U. Characterization of white tea - comparison to green and black tea. J Con Prot Food Saf. 2007;2(4):414-421. DOI: 10.1007/s00003-007-0250-3.

5. Balentine DA, Wiseman SA, Bouwens LC. The chemistry of tea flavonoids. Crit Rev Food Sci Nutr. 1997;37(8):693-704. DOI: $10.1080 / 10408399709527797$.

6. Haslam E. Thoughts on thearubigins. Phytochem. 2003;64(1):61-73. DOI: $10.1016 / \mathrm{s} 0031-9422(03) 00355-8$
7. Yang CS, Ju J, Lu G, Xiao H, Hao X, Sang S, Lambert JD. Cancer prevention by tea and tea polyphenols. Asia Pac J Clin Nutr. 2008;17(1):245-248. PMID: 18296347

8. Sharma V, Rao LJ. A thought on the biological activities of black tea. Crit Rev Food Sci Nutr. 2009;49(5):379-404. DOI: 10.1080/10408390802068066

9. Kumar G, Pillare SP, Maru GB. Black tea polyphenols-mediated in vivo cellular responses during carcinogenesis. Mini Rev Med Chem. 2010;10(6):492-505. DOI: 10.2174/138955710791384063

10. Kuhnert N. Unraveling the structure of the black tea thearubigins. Arch Biochem Biophys. 2010;501(1):37-51. DOI: 10.1016/j.abb.2010.04.013

11. Kuhnert N, Drynan JW, Obuchowicz J, Clifford MN, Witt M. Mass spectrometry characterization of black tea thearubigins leading to an oxidative cascade hypothesis for thearubigin formation. Rapid Commun Mass Spectrom. 2010;24(23):3387-3404. DOI: $10.1002 / \mathrm{rcm} .4778$

12. Blot WJ, McLaughlin JK, Chow WH. Cancer rates among drinkers of black tea. Crit Rev Food Sci Nutr. 1997;37(8)739-760. DOI: $\underline{10.1080 / 10408399709527800}$

13. Neyestani TR, Gharavi A, Kalayi A. Selective effects of tea extract and its phenolic compounds on human peripheral blood mononuclear cell cytokine secretions. Int J Food Sci Nutr. 2009;60(1):79-88. DOI: $10.1080 / 09637480802158184$

14. Jezovicová M, Konarikova K, Durackova Z, Kerestes J, Králik G, Zitnanová I. Protective effects of black tea extract against oxidative DNA damage in human lymphocytes. Mol Med Rep. 2016;13(2):1839-1844. DOI: 10.3892/mmr.2015.4747

15. Liu S, Huang H. Assessments of antioxidant effect of black tea extract and its reationals by erithrocyte haemolysis assay, plasma oxidation assay and cellular antioxidant activity (CAA) assay. J Funct Foods. 2015;18(part B):1095-1105. DOI: 10.1016/j.jff.2014.08.023

16. Hodgson JM, Puddey IB, Woodman RJ, Mulder TP, Fuchs D, Scott $\mathrm{K}$, Croft KD. Effects of black tea on blood pressure: a randomized controlled trial. Arch Intern Med. 2012;172(2):186-188. DOI: 10.1001/archinte.172.2.186

17. Steptoe A, Gibson EL, Vuononvirta R, Hamer M, Wardle J, Rycroft JA, Martin JF, Erusalimsky JD. The effects of chronic tea intake on platelet activation and inflammation: a double-blind placebocontrolled trial. Atherosclerosis. 2007;193(2):277-282. DOI: 10.1016/j.atherosclerosis.2006.08.054

18. Baker JA, Boakye K, McCann SE, Beehler GP, Rodabaugh K, Villella JA, Moysich KB. Consumption of black tea or coffee and risk of ovarian cancer. Int J Gynecol Cancer. 2007;17(1):50-54. DOI: 10.1111/j.1525-1438.2006.00773.x

19. Cassidy A, Huang T, Rice MS, Rimm EB, Tworoger SS. Intake of dietary flavonoids and risk of epithelial ovarian cancer. Am J Clin Nutr. 2014;100(15):1344-1351. DOI: 10.3945/ajcn.114.088708

20. Wang L, Zhang X, Liu J, Shen L, Li Z. Tea consumption and lung cancer risk: a meta-analysis of case-control and cohort studies. Nutr. 2014;30(10):1122-1127. DOI: 10.1016/j.nut.2014.02.023

21. Sarkar A, Bhaduri AN. Black tea is a powerful chemopreventor of reaction oxygen and nitrogen species. Comparison with its individual catechin constituents and green tea. Biochem Biophys Res Commun. 2001;284(1):173-178. DOI: 10.1006/bbrc.2001.4944

22. Maity S, Ukil A, Vedasiromoni JR, Das PK. Biodistribution and pharmacokinetics of Theaflavin-3,3'-Digallate, the major antioxidant of black Tea, in Mice. Intl J Pharmacol. 2006;2(2):240-246. DOI: 10.3923/ijp.2006.240.246

23. Sherry $\mathrm{CHH}$, Iman AH. Pharmacokinetic and chemoprevention studies on tea in humans. Pharmacol Res. 2011;64(2):105-112. DOI: 10.1016/j.phrs.2011.05.007

24. Lee MJ, Maliakal P, Chen L, Meng X, Bondoc FY, Prabhu S, Lambert G, Mohr S, Yang CS. Pharmacokinetics of tea catechins after ingestion of green tea and (-)-epigallocatechin-3-gallate by humans: formation of different metabolites and individual variability. Cancer 
Epidemiol Biol Preven. 2002;11(10Pt1):1025-1032. DOI: $10.1017 / \mathrm{S} 0007114507898692$

25. Mulder TP, van Platerink CJ, Wijnand Schuyl PJ, van Amelsvoort JM. Analysis of theaflavins in biological fluids using liquid chromatography-electrospray mass spectrometry. J Chromatogr B Biomed Sci Appl. 2001;760(2):271-279. DOI: 10.1016/S03784347(01)00285-7

26. Daariimaa K, Mandakhnaran $\mathrm{P}$, Batgerel L, Sarantsetseg B, Davaasuren $\mathrm{T}$, Tsetsegmaa $\mathrm{S}$, Enkhjargal D, Ambaga $\mathrm{M}$. The hepatoprotective activity of the herbal preparation Salivin against carbon tetrachloride $\left(\mathrm{CCl}_{4}\right)$ induced hepatotoxicity in rabbits. Curr Issues Pharm Med Sci. 2014;27(4):263-266. DOI: 10.1515/cipms2015-0030

27. Shargel L, Susanna Wu-P, Andrew BC. Applied biopharmaceutics and pharmacokinetics. $6^{\text {th }}$ ed. New York: McGraw-Hill Education; 2012. Pp:767

28. Nuh K. A Comparison between medetomidine-ketamine and xylazineketamine anaesthesia in rabbits. Turk J Vet Anim Sci. 2004;28:921926. DOI: $10.1258 / 002367797780600215$

29. Lee MJ, Wang ZY, Li H, Chen L, Sun Y, Gobbo S, Balentine DA, Yang CS. Analysis of plasma and urinary tea polyphenols in human subjects. Cancer Epidemiol Biol Prev. 1995;4(4):393-399. PMID: 7655336

30. SAS. Statistical Analysis System, User's Guide. Statistical. Version 9.1 ${ }^{\text {th }}$ ed. New York: SAS Inst Inc; 2012.

31. Nada SA, Omara EA, Abdel-Salam OM, Zahran HG. Mushroom insoluble polysaccharides prevent carbon tetrachloride-induced hepatotoxicity in rat. Food Chem Toxicol. 2010;48(11):3184-3188. DOI: $10.1016 /$ j.fct.2010.08.019

32. Ilavenil S, Kaleeswaran B, Ravikumar S. Protective effects of lycorine against carbon tetrachloride induced hepatotoxicity in Swiss albino mice. Fundam Clin Pharmacol. 2011;26(3):393-401. DOI: 10.1111/j.1472-8206.2011.00942.x
33. Alaraj MA, Qiblawi SB. Protective Effects of fish oil on carbon tetrachloride induced hepatotoxicity in rabbits. The Inter J Sci Basic Appl Res. 2015;19(2):400-408.

34. Henning SM, Niu Y, Lee NH, Thames GD, Minutti RR, Wang H, Go VL, Heber D. Bioavailability and antioxidant activity of tea flavanols after consumption of green tea, black tea, or a green tea extract supplement. Am J Clin Nutr. 2004;80(6):1558-1564. DOI: 10.1093/ajcn/80.6.1558

35. Kao YH, Hiipakka RA, Liao S. Modulation of endocrine systems and food intake by green tea epigallocatechin gallate. Endocrinol. 2000;141(3):980-987. DOI: 10.1210/endo.141.3.7368

36. Chen HD, Hayek S, Guzman JR, Gillitt ND, Ibrahim SA, Jobin C, Sang SM. The microbiota is essential for the generation of black tea theaflavins-derived metabolites. PLoS One. 2012;7(12): 1-10. e51001. DOI: 10.1371/journal.pone.0051001

37. Magdalou J, Antoine B, Ratanasavanh D, Siest G. Phenobarbital induction of cytochrome p-450 and UDP glucuronosyl transferase in rabbit liver plasma membranes. Enzyme. 1982;28(1):41-47. DOI: $10.1042 / \mathrm{bj} 2810577$

38. Little JM, Drake RR, Vonk R, Kuipers F, Lester R, Radominska A. Characterization of human liver microsomal UD Pglycosyl transferases using photoaffinity analogs. J Pharmacol Exp Ther. 1995;273(3):1551-1559. PMID: 791131

39. Runge-Morris M, Kocarek TA, Falany CN. Regulation of the cytosolic sulfotransferases by nuclear receptors. Drug Metab Rev. 2013;45(1):15-33. DOI: 10.3109/03602532.2012.748794

40. $\mathrm{Lu} \mathrm{H}$. Mechanistic studies on the phase II metabolism and absorption of tea catechins (2002). [PhD dissertation], New Brunswick: The State University of New Jersey; 2002: 98-99.

41. Chen H, Parks TA, Chen X, Gillitt ND, Jobin C, Sang S. Structural identification of mouse fecal metabolites of theaflavin-3,3ф-digallate using liquid chromatography tandem mass spectrometry. J Chromatogr A. 2011;1218(41):7297-7306. DOI: 10.1016/j.chroma.2011.08.056. 